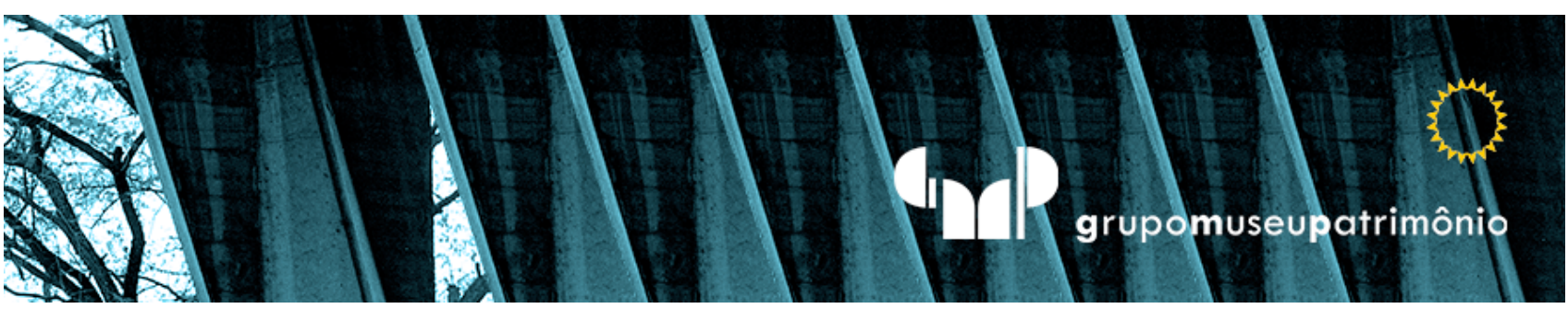

\title{
Luzes, câmera, interrupções: 20202021
}

\author{
Luces, cámara, \\ interrupciones: 20202021
}

Lights, camera, interruptions: 20202021

Maria Cecília França Lourenco

Profa. Titular da Faculdade de Arquitetura e Urbanismo FAU USP, São

Paulo,BRA.mcfloure@usp.br 


\section{Resumo}

Neste texto, deseja-se abordar o tempo de espera em questões atuais, em particular, ao se rever status de atribuição de valor, a incluir os aferidos na área museal. Analisam-se idas-e-vindas do colonialismo, tema iminente e em ato inicial. Na pandemia da Covid-19, em oposição ao luto estonteante, floreceram ações há muito requeridas em repatriação de obras, reparação de valor, associadas ao refluir de luzes e veto à cultura em presença. Somem-se a estes fatores, a ausência de política eficaz ante a crise, nas várias esferas geopolíticas. Belas falas sobram, sobre combate na crise em inúmeros setores, social/farmaco/sanitário e acerca de metas e apoio escolar. Inclue-se a volta de bens culturais exilados em países expansionistas, cuja antiga musealização se vê abalada por. rogos de muitos países para devolução de tal patrimônio

Palavras-Clave: Reparação. Museus. Pandemia. Decolonialismo. Conflito

\section{Resumen}

En este texto, queremos abordar el tiempo de espera en focos actuales, en particular, al revisar el estado de asignación de valor, para incluir los medidos en el área museal. Analizamos las idas y venidas del colonialismo, un tema inminente y en un acto inicial. En la pandemia de Covid-19, frente al impresionante luto, florecieron las acciones largamente requeridas en la repatriación de obras, la reparación de valor, asociada al reflujo de luces y el veto a la cultura en presencia. A estos factores se suma la ausencia de una política eficaz ante la crisis, en los distintos ámbitos geopolíticos. Quedan hermosas declaraciones, sobre la lucha contra la crisis en numerosos sectores, sociales/ farmacológicos / sanitarios y sobre los objetivos y el apoyo escolar. El regreso de los bienes culturales exiliados en países expansionistas, cuya antigua musealización se ve sacudida por solicitudes de muchos países de restitución de esos activos

Palabras-Clave: Reparatión Museos. Pandemia. Decolonialismo. Conflito

\section{Abstract}

In this text, we want to address the waiting time on current issues, in special, when reviewing value assignment status, to include in the museal area. We analyze the comings-and-going of colonialism, an imminent theme and in an initial act. In the Covid19 pandemic, as opposed to the stunning mourning, long-required actions in repatriation of works, reparation of value, associated with the reflow of lights and veto to the culture in presence, flourished. Add to these factors, the absence of effective policy in the face of the crisis, in the various geopolitical spheres. Beautiful talks remain, about combating the crisis in numerous sectors, social/pharmaco/sanitary and about goals and school support. The return of cultural goods exiled in expansionist countries, whose former musealization is shaken from many countries for the return of such assets..

Keywords: Reparation. Museums. Pandemic. Decolonialism. Conflicts. 


\section{INTRODUÇÃO}

A biografia de qualquer ser humano contém rupturas que parecem abrir um novo período na vida. Alterações bruscas na experiência o forçam a abandonar as trilhas habituais e abrir outras vias. A consciência precisa processar as novas experiências.

Quando se transpõem limiares, muito, talvez tudo, se apresenta de modo diferente, dependendo do grau em que somos afetados e tomamos consciência disso. (KOSELLECK, 2014, p.247)

ano de 2021 desvelou meandros em variados setores, seja na preservação da vida, fosso social, ou no cotidiano em geral. Emergiram bastidores também na cena cultural, antes privados apenas aos atuantes. A constatação enseja reflexão para além dos informes oficiais ${ }^{1}$, não raro, a desprezar o cidadão atento, a analisar narrativas. Realço que o humano ao se defrontar com fato raro, a impactar o

\footnotetext{
${ }^{1} \mathrm{O}$ texto compõe a pesquisa "Intra museus: acesso liberado?" relativa à fase atual do Projeto de Professor Titular Sênior, na Faculdade de Arquitetura e Urbanismo da Universidade de São Paulo/FAU USP. Desde janeiro de 2021, desenvolvo em diálogo com o Grupo Museu/Patrimônio, neste ano completando 30 anos, cada um com sua pesquisa e criação, sempre renovada e a quem agradeço trocas, debates, visita técnica, estudos e seminários.
} 
viver, arrisca saídas para reverter rumos pessoais e coletivos, como bem define Reinhart Koselleck. Isto não se constata na hora atual, por atores com lugar público de fala e ato.

Sobre ações no coletivo, veja-se a demora de governos, em variada geopolítica, para adotar medidas antipopulares e forçosas, cito, o fechamento total de cidades e o informe real de dados. Ademais, aqui e em outros países disseminaram-se planos e soluções mágicas, ao anunciar espetáculo midiático com a chegada de vacinas, apoio de difusores de ciência às medidas estatais, uso de remédio, para pseudo cura não comprovada por testes. Se no lugar de simular houvesse testagem e campanha para cuidados individuais, talvez se evitassem mortes, colapso hospitalar e mutação em cepas do coronavírus.

Antes, em 2020, a globalização financeira e a mundialização cultural se mostraram vivazes ao criar fetiches, quanto à doença e à vacina, esta tida como saída redentora. Sem dúvida, a rapidez e eficácia residem em vitória da pesquisa, ainda que haja cortes nas verbas ${ }^{2}$, em hora com total absurdo de vidas perdidas. No entanto, a má política segue proclamando estoque de doses, para já e a todos, quimeras de desgoverno. Vozes pulsantes no urbano apontam as falsas afirmações de poderes. Artistas, criam alerta no espaço urbano, como em "Ligue os pontos" em forma de cruz, quando em 24 de março de 2021 surgiu a nefasta marca de 300.000 cidadãos mortos.

\footnotetext{
${ }^{2}$ Desde o final de 2020 vozes e órgãos atentaram ao perigo de corte orçamentário nas várias universidades afeitas ao Ministério da Ciência, Tecnologia e Inovação, em Bolsa de Pesquisa e Censo Demográfico, quando a pandemia se mostra ainda mais agressiva. Em 23 de abril de 2021 noticiou-se refluxo e, mesmo, cancelamento do Censo, quando o próprio Ministro chamou de 'estrago'após a oficialização. Uma vez mais houve judialização para exigir que se efetive o óbvio.
} 


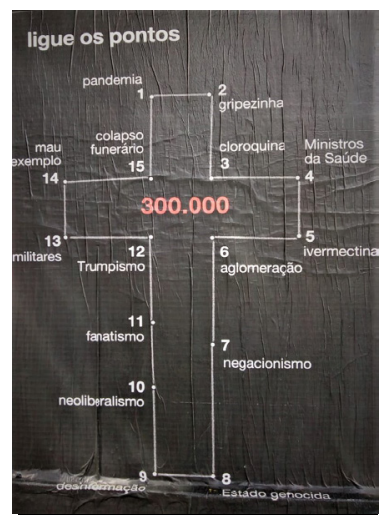

Figura 1: "Ligue os Pontos". Rua Cardeal Arcoverde/ SP. Gráfica Fidalga. Foto: A. em 6 abr. 2021

Lenda usual no campo educacional tem sido a alegação sobre ingresso em aula remota e aos recursos em tecnologia, para ensino, a englobar periferias no país. Falta acesso, trocas e interação social para incentivo e elucidação de dúvidas, dificuldades de pais para suprir inúmeros obstáculos, o mais usual seria a ausência no local de moradia, já que buscam trabalho para se manter. Pergunta-se: como os alunos se socializam? Quem provê défices efetivos em aprendizagem? Amparo eficaz a mestres e escolas constitui outro mito, ao lado de limites ao ativismo. Impedidos de se aglomerar, falas expressivas revelam dificuldades em atingir os demais.

Docentes nas escolas públicas sofreram sem apoio para colocar crédito no celular, treino anterior, suporte técnico nas falhas, amparo nas salas, avaliação à distância e, mesmo, obtenção de itens básicos: pacote de dados, aparelhos funcionais e potentes, aplicativos, Wi-FI sem custos. Vacina para todos foi preterida, ante a restrita oferta de insumos, previsão e diversificação de fabricantes e privilegiar saúde e não engodo e projeção política. Pior, o conjunto procede de disputas rasas, na corrida eleitoral. Assim, trabalhadores em setores de serviços gerais e técnicos, foram incluídos para ser vacinados apenas em março de 2021, reiterando-se o hiato nefasto entre fala e ação.

Na Covid-19, mudou-se o cotidiano, em todas as faixas sociais, etárias e laborais. Aqui o foco reside no museal, uma parte que espelha o todo, pois, rotinas diárias devem seguir. Este texto pauta-se pelo tema: "Outro ato: em direção ao caminho 
inverso", em diálogo, com o de Clarice Lispector, escolhido pelo Conselho Editorial da Revista ARA FAU USP. Museu funda cena peculiar e não pode parar, embora fechado à visita e parte de funcionários siga afastada ou desligada. Então, pergunta-se: como manter as coleções, se se trabalha à distância, como tratar a memória do outro, agora modificada ${ }^{3}$ ?

Importante lembrar que toda história se funda em valores de quem seleciona, pesquisa e redige, nunca sendo uma única compreensão. O palenteólogo e historiador francês, dedicado ao estudo das Américas, Serge Gruzinsk alude ao fato de que se busque interpretar os momentos de convivência e encontro entre, numa espécie de mestiçagem. Cria analogias esclarecedoras e em diferentes momentos, ao comparar o historiador a uma espécie de eletricista e, em outro, a um restaurador. Neste grave momento urge ativar as fronteiras entre dito e escondido, até mesmo para superar os desvios.

Quanto à relação referida ao eletricista, Gruzinski (2003) alude ao imperativo de se refazer e ampliar redes, para além do habitual e oculto. Justifica-se pelo fato de que deve “[...] restabelecer as conexões internacionais e intercontinentais que as historiografias nacionais e as histórias culturais desligaram ou esconderam, entaipando as suas respectivas fronteiras". No tocante ao restaurador, acrescenta, que para o historiador nada se acha acabado e, assim, se assemelha a este "[...] que jamais esquece que o objeto por ele restaurado [...] não tem nada de um original, mas sim é fruto de construções anteriores [...] a serem refeitos incessantemente $(2015$, p.96)

A historiadora de arte espanhola Anna Maria Guasch ao elaborar curadoria da exposição, La memoria del outro, no Museu Nacional de Belas Artes de Santiago do Chile ponderou no catálogo (2010) algo distinto e oportuno: acena para se suplantar o multiculturalismo, típico do final do século passado, para o

\footnotetext{
${ }^{3}$ Note-se que museu, instituto, arquivo, biblioteca, centro cultural, entre alguns, detentores de acervos e coleções requerem condições de conservar, quanto à luz, temperatura ambiente, aramazenamento, suportes, segurança e, por vezes, restauro, a par de pesquisar, documentar, salvaguardar e extroverter para público diverso, funções estas cotidianas.
} 
interculruralismo no âmbito da memória. Exige-se encarar, tanto o desafio em atuar com valores opostos, quanto criar formas para intercâmbios e metodologias em trocas para novo público. No lugar de se analisar povos a convergir, Guasch propõe diálogo entre culturas distintas,

No âmbito do bilaterismo de base centra todo seu sentido no diálogo entre culturas, baseadas na relação eu/tu-tu/eu em que cada uma das partes reconhece no outro uma 'pessoa', isto é um 'fim' em si mesmo e não um 'meio' para conseguir' um objetivo. Um diálogo que consiga superar o multiculturalismo pela filosofia política do 'interculturalismo', vale dizer, a do intercâmbio cultural por meio de processos internacionais. Se tem que avançar para o 'intercultural' que supera a antiga dicotomia identidade/diferença, que fazia diálogos entre distintos contextos nacionais por meio de uma maior potência entre subjetividades [...] $(2010$, p.22) .

Pensamento similar constata-se em outra conceituação formulada por Gruzinski, que em distintos textos defende a demanda por estudo de povos interligados e assim, propõe que se superem "[...] esquemas simplistas de alteridade - para os quais a história se reduz ao confronto nós e os outros - e a substitui-los a enredos mais complexos" (2015, p.348). Reitera também a importância em se rejeitar o eurocentrismo. Argumenta que este se dá, não por mera ética desgastada do politicamente correto, mas sim, de modo a compreender "[...] o mundo que hoje nos rodeia passa pela explosão de molduras multisseculares, dentro das quais a memória histórica continua a operar" (Idem ibidem).

Defende-se que estender saber demanda gerar ação em dupla mão, porquanto implica em se apartar de posições dogmáticas, fundamentalistas, catequistas e altaneiras. Nestas atitudes, quem atua prima pelo desejo em irradiar o próprio valor e saber para o tal Outro, por vezes tido como sem valor, face ou importância

\footnotetext{
${ }^{4}$ En el ámbito de este bilateralismo de base, cobra todo su sentido el diálogo entre culturas que plantea una relación del tipo "yo/tú-tú/yo" en la que cada una de las partes reconoce en el otro a una "persona", es decir, a un "fin" en sí mismo y no a un "medio" para conseguir un objetivo. Un diálogo que permite superar la fase del multiculturalismo por la filosofía política del "interculturalismo", es decir, la del intercambio cultural a través de procesos inter-nacionales, con lo que ello supone de nueva reapropiación crítica de lo nacional. Se tiene que avanzar pues hacia lo "intercultural" que supera la antigua dicotomía identidad/diferencia y hacia los diálogos entre distintos contextos nacionales a través de una mayor potenciación de las subjetividades [...] (Tradução A.)
} 
comparados aos de quem avalia equivocadamente. Ante o caos sanitário, recomendações e revisão em funções consagradas na esfera museal vêm ocorrendo, por meio de debate conceitual e alargado, liderado pelo Conselho Internacional de Museus - ICOM, afinado aos reclamos sociais e de costas para o corporativismo, assim, abrindo-se a recém convidados.

Quanto ao âmbito do patrimônio, pretende-se avaliar questões ligadas à reparação, conflitos e decolonialismo, pleitos forçosos para o humano, em muitas regiões, com agudo acento simbólico, que clamam por alterações. Acompanho Homi K. Bhabha ao afirmar sobre o tema: "A pós-colonialidade, por sua vez, é um salutar lembrete das relações 'neocoloniais' remanescentes no interior da 'nova' ordem mundial e da divisão de trabalho multinacional" (1998, p. 26). Há iminência em revê-las, em relação horizontal com o Outro. Ao se deparar com a pandemia, museus se abriram para esgarçar fendas e seguir em diálogo digital. O público curioso aderiu como lazer e apoio, porém, os recursos se esvaíram, dada a miríade de ações forçosas para se resolver na telinha, para os que as têm e podem operá-las.

Grandes redes tecnológicas vêm atraíndo instituições a fixar-se em suas plataformas, com pretenso serviço gratuito, na verdade, forma de usupar conteúdo, formas e dados. Estes originam recursos apenas para as tais empresas, como Google e a versão Art \& Culture, Facebook, ou redes, a citar You Tube, Facebook, Instagram e Tik Tok, entre outras. Não se trata de inovação, porquanto, há muito firmas operam em setores de textos e imagens, apropriando-se de criação artísticas, estudiosos, material informativo ou crítico. Na verdade, controlam produção, circulação, fruição do que se realiza em múltiplos campos, a incluir o do saber, travertidos em altas cifras.

Ao contrário, práticas museais abrigam sitemática cadeia operatória, inviável de se parar, em especial na pandemia e vão além de segurança, controle térmico e de umidade. $\mathrm{O}$ ciclo para se preservar abarca etapas para além de informar dados e circunstâncias. Reitero: envolve desde a seleção, registro, conservação, difusão, até restauro, pesquisa sobre origem, técnica e caminho trilhado anteriormente, com finalidades objetivas: desvelar sentidos em tempos distintos, relações de semelhança 
e diferença, gerar conteúdo em variados níveis, educar para consciência crítica, cidadania e trocas externas.

Sobre o quesito reparação, neste início realço a justa premiação conferida, in memoriam à arquiteta, brasileira por opção, Lina Bo, em maio de 2021, ante o conjunto da obra, na 17a. Mostra Internacional de Arquitetura da Bienal de Veneza/ ITA. Chega quando o país se acha desgastado no mundo, a abranger da política ao meio ambiente, mais o precário combate a Covid-19. De acordo com o curador Hashim Sarkis (2021), no Site da Bienal de Veneza ao justificar o prêmio, salienta que Lina ultrapassa as soluções arquitetônicas: "Sua carreira como designer, editora, curadora e ativista nos lembra do papel do arquiteto como organizador e, mais importante, como construtor de visões coletivas".

Sarkis (2021) juntou no Site, algo da postura dela, fundamental para este momento: “[...] perseverança da arquiteta em tempos difíceis, sejam guerras, conflitos políticos ou imigração, e sua capacidade de permanecer criativa, generosa e otimista durante todo o tempo." Politizada e certeira no foco, curadora atenta ao popular, uma das pioneiras no desenho gráfico, autora de projetos marcos no âmbito museal, ${ }^{5}$ venceu prêmio ímpar: ante o conjunto da obra e após a morte; antes, apenas Kazuo Shinohara obtivera a mesma láurea (2006).

\footnotetext{
5 - Inúmeros são os projetos museais de Lina Bo, porém, ressalto um autoral, engajado e com foco inédito na preservação do moderno, para o no Museu de Arte Moderna/BA, reitero que, deste foi expulsa pelos mandatários, após o Golpe de 1964. Como antes defendi, criou um programa singular, após transferir-se "[...] para Salvador e inicia etapa distinta de sua vida, em que vai dar formas e sonhos [...]" (LOURENÇO, 1999, p.177)
} 


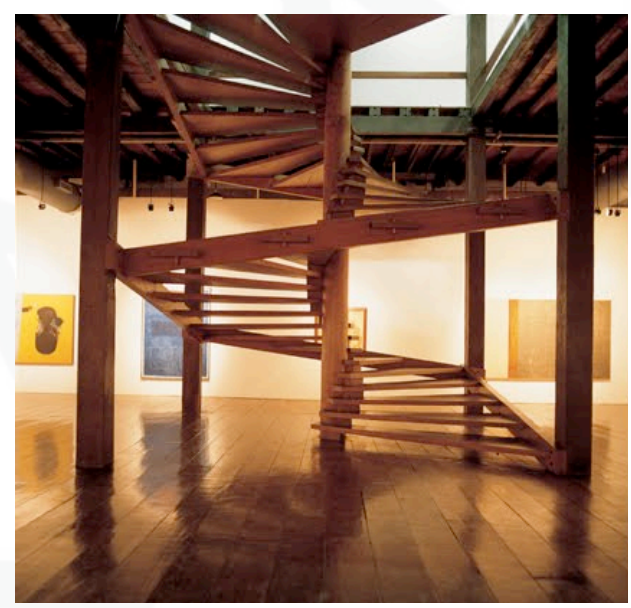

Figura 2: Lina Bo. Rehabilitação do espaço no Solar do Unhão para instalação do Museu de Arte Moderna/MAM. Salvador/BA. Fonte: Foto A. 1998.

\section{RESTITUIÇÃO: DESCONSTRUÇÃO DE NARRATIVAS}

Ora, assim como essas idéias se movem no espaço, há de acontecer que também viajem no tempo, e porventura mais depressa do que os suportes, passando a reagir sobre condições diferentes que venham a encontrar ao longo do caminho. (HOLANDA, 2000, p. XIX-XX)

Aspecto admirável observou-se ao se anunciar intenções para repatriamento e, mesmo, retirada de partes humanas e peças rituais de povos distintos exibidas em museus. Ainda que se trate de discurso e debate inicial, representam o caminho inverso em posições milenares na questão de incrustar valores de poder em coleções, desde os primórdios dessa prática, na Antiguidade greco-romana. Tal mutação, parece querer apagar rastros lastimáveis na relação com o Outro, reduzindo pessoas e mesmo objetos a uma espécie de troféu, a indicar elevação de uns sobre adversários, de modo a justificar crimes e reduzi-los a subalternos, que demandariam proteção.

Ações temporárias ganham o espaço público amplificando alertas sobre a situação atual. Alastraram-se criações e cores no urbano, diretas ou sutis. Assim veem-se em empenas de edifícios conteúdo óbvio, via projeção e grafites, por vezes decorativos. Mais raras constituem-se em instalações bizarras sobre tema atual, como se constata abaixo, quando se pedia saída do Ministro do Meio Ambiente, em face de um 
conjunto de medidas, que apontavam para retrocesso de conquistas, fulcrais para essa área ${ }^{6}$.

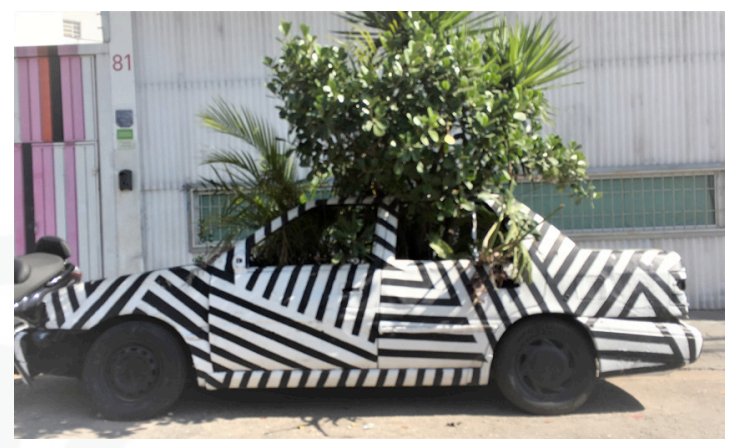

Figura 3 : Instalação na Rua Padre João Gonçalves Pinheiros/SP. Foto A, 26.06.2021.

As lutas pela preservação de bens culturais foram encampadas por órgãos supranacionais, como a Organização das Nações Unidas (ONU), com atuação da agência Organização das Nações Unidas para a Educação, a Ciência e a Cultura (UNESCO), que em 1970 levantou a questão do tráfico ilícito de patrimônio, chamando a atenção sobre o tema. Data de 1987 Resolução relativa ao retorno ou restituição compartilhada, para os países originários de bens culturais, de forma a sublinhar relevante problema, ou seja, o de quem teria direito de fato para manter peças de outros povos.

Importante aspecto para restituição de bens obtidos em decorrência de guerras, efetuou-se com a assinatura em 1972 da Convenção para a Proteção do Patrimônio Mundial, Cultural e Natural, na Conferência Geral da UNESCO. Em 1978, estando a América Latina exaurida por ditaduras e terrorismo de estado, no órgão, instituiu-se o comitê intergovernamental para promover o retorno de bens culturais a seus países de origem, ou sua restituição em caso de apropriação ilícita.

\footnotetext{
${ }^{6}$ Incluem-se fala equivocada do então Ministro Ricardo Salles em reunião sobre a oportunidade em se abandonar leis protetivas, por haver noticiário centrado na pandemia; intenção em mudar as regras de uso financeiro do Fundo da Amazônia; falta de investimentos previstos para proteção ambiental; investigação criminal por suposta atuação ilegal a favor de madeireiros; incêndios, maior desmatamento na Amazônia, desde 2008; invasão de terras protegidas na Amazônia e em outros biomas.
} 
Mandatários abalados pela hipótese de desmonte em suas coleções museais, em consequência da legislação acordada, inúmeros países colonialistas ignoraram os argumentos e adiaram muito a ratificação habitual desses atos ${ }^{7}$. Lista significativa sobre a demora de países colonialistas para devolver a quem de direito foi feita pelo Comitê Intergovernamental para a Promoção da Devolução de Bens Culturais para seu País de Origem ou sua Restituição em caso de apropriação llegal:

2011: Alemanha - Turquia

No início de maio de 2011, o Secretariado foi informado de que um acordo bilateral havia sido alcançado entre a Alemanha e a Turquia com relação à Esfinge de Bogazkoy. Este caso foi apresentado ao Comitê em 1987.

2010: Museu Barbier-Mueller (Suíça) - República Unida da Tanzânia

Em maio de 2010, o Museu Barbier-Mueller (Genebra) devolveu uma máscara Makondé à República Unida da Tanzânia. As discussões começaram no Comitê em 2006.

1988: Estados Unidos - Tailândia

Em 1988, os Estados Unidos devolveram o lintel de Phra Narai à Tailândia. O caso foi resolvido por meio de mediação.

1987: República Democrática Alemã - Turquia

Em 1987, a República Democrática Alemã devolveu à Turquia 7.000 tabletes cuneiformes de Bogazköy. O caso foi resolvido com a devolução direta dos objetos em questão.

1986: Museu de Arte de Cincinnati (Estados Unidos) - Jordânia

Como parte de um intercâmbio e na sequência de um pedido apresentado pela Jordânia em 1983 ao Comitê Intergovernamental, o Museu de Arte de Cincinnati (Estados Unidos) e o Departamento de Antiguidades de Amã (Jordânia) decidiram: em 1986, para a troca dos moldes das respectivas partes do disco de arenito Tyche e do zodíaco que estavam em sua posse, a fim de poder apresentar a obra na íntegra. Este caso foi resolvido por meio de mediação.

1983: Itália - Equador

Em 1983, a Itália devolveu ao Equador mais de 12.000 objetos pré-colombianos. O caso foi resolvido após um litígio de sete anos. $\mathrm{O}$ apoio moral do Comitê foi reconhecido pelas autoridades equatorianas como um fator significativo para o sucesso de sua causa.

Figura 4: Quadro demonstrativo da demora em aderir à determinação de devolução. Fonte: http://www.unesco.org/new/fr/culture/themes/restitution-of-cultural-property/committessuccessful-restitutions/ Acesso em: 12 maio 2021

Órgãos internacionais, como a interpol, divulgam roubos de peças. Na pandemia alertaram acerca de roubo de jóias, em 23 de abril de 2020, estando fechado o Museu Green Vault, na cidade de Dresden, na Alemanha. A iniciativa no âmbito de mídias digitais muito contribui para inibir ações predatórias e posse ilegal, assim contribuindo para restituição de obras registradas como crime.

\footnotetext{
${ }^{7}$ Segundo a UNESCO, França assinou a resolução de 1987, dez anos depois, Reino Unido, em 2002, Alemanha em 2007 e Bélgica em 2009. Por outro lado, apenas em 2011 Alemanha e a Turquia entraram em acordo para repatriação da Esfinge de Bogazkoy, entre outras delongas.
} 


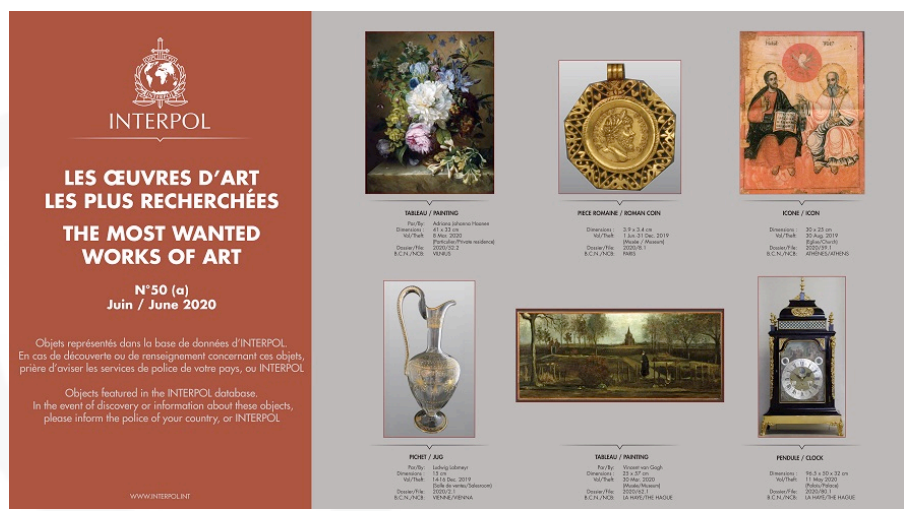

Figura 5: Interpol. Obras de arte as mais procuradas. Fonte: https:///www.portal.iphan.gov.bder/noticias/talhes/5735/ Acesso em 28.06.2020.

Neste século (2002) algumas instituições europeias buscaram apoio para manter coleções de outros povos em oposição ao retorno. Redigiu-se a "Declaração sobre a importância e o valor dos museus universais", cito o British Museum, o Louvre, o Metropolitan Museum of Art/NY, o Prado de Madri, o Rijksmuseum de Amsterdam e o Hermitage de São Petersburgo.

O termo universal constitui-se também em algo discutível, uma espécie de fábula, tanto para justificar posse de formas de Outro, interesse em dissimular intenções e aparentar bons princípios; quanto espelhar isenção na atribuição de valores. Ressaltem-se no quesito justificativa simplistas, a fala comum de que órgãos preservacionistas europeus, como museus, bibliotecas e arquivos detêm condições superiores no domínio técnico voltado à conservação e investigação, ao contrário dos demais, o que abonaria manter corpos, símbolos e sinais, desta forma estendendo o colonialismo. Por que não trocam saber?

Immanuel Wallerstein em seus esforços decoloniais acentua o papel de estudos culturais para a crítica na adoção de valores universalistas, sobre cânones, normas e leis. O iminente sociólogo estadunidense lembra "[...] a necessidade em se evitar a inclusão apenas de características, não raro, emergidas de um grupo específico, a saber: "[...] - homens brancos ocidentais de grupos étnicos dominantes -, que afirmavam de maneira arrogante, que seus conjuntos particulares de valores eram universais" (2007, p. 104-5). 
Inúmeros pedidos há muito vêm sendo anunciados, ficando claro que, para além de peças raras, formas musealizadas, de inúmerosos povos, agem semelhante a uma metomínia, ou seja, uma retórica para abalar o todo, ao se deter dada parte. Saliente-se que, após quase um século, em 2010, o Governo peruano reiterou pedido para se recambiar artefatos incas, retirados de Machu Picchu/Cusco e cedidos, por 18 meses, à Universidade de Yale/EUA, em 1911. Após a negativa, no ano seguinte por ação de um senador, assinam protocolo Yale e a Nacional de San Antonio Abad para repatriamento.

No mesmo ano (2010), por ocasião dos 140 anos do final da Guerra entre Paraguai, Brasil, Uruguai e Argentina o governo do primeiro solicitou ao segundo a devolução de um canhão exposto no Museu Histórico Nacional/RJ (MHN). Inserido no Livro de Tombo Histórico (1997) como parte da coleção do referido MHN, pelo órgão competente, caberia ao então Presidente Luiz Inácio Lula da Silva ${ }^{8}$ retirar tal classificação para depois atender à demanda.

Provalvelmente ciente sobre os conflitos, que a decisão de repatriar causaria com setores estratégicos, o então presidente sondou áreas envolvidas, havendo uma ação popular contrária à restituição. Novos apelos sucederam-se, sem sucesso, incidindo em legitimidade da posse brasileira. O canhão simularia uma ação inovidável? Camuflaria a matança da guerra? Nutriria a simbologia deplorável, voltada a demarcar dominação desse vizinho? Abalaria pretensa identidade vitoriosa nesse conflito? O diálogo desejável faria erodir o senso de vitória e controle, ao se concretizar a volta da peça?

Durante a atual pandemia alguns museus vêm reagindo rapidamente e sintonizando-se a clamores em temas culturais, das bordas sociais ainda invisíveis. Então se indaga: teria a introspecção desse período conferido vivacidade a estes e em direção inversa? Formou-se variada gama de reações e há os que se senbilizaram a rever exibição absurda de partes humanas, após anos dessa lúgubre

\footnotetext{
${ }^{8}$ A afirmação fundamenta-se no Decreto-lei no 25, de 30 de novembro de 1937.
} 
prática $^{9}$; mais, alguns estão sendo instados a devolver tanto objetos de culto para segmentos primeiros, exibidos como obra de arte, quanto recolocadas peças extorquidas por falastrões, que enganam multidões, como o caso nazista. Em direção divergente, reapareceram objetos roubados, posteriormente negociados e que retornaram a museus, após anos.

Por outra face, o caso do Museu Histórico do Estado situado em Moscou/RUS, demonstra como se pode esconder em museus acervos que desapareceram. Durante a pandemia o arqueólogo ucraniano Tymur Bobrovsky pesquisando o material digital encontrou parte de coleção desaparecida de um dos mosteiros cristão ortodoxo, o Conjunto Histórico e Cultural de Kiev Pechersk Lavra, em 1930, como se divulgou (MALVA, 6 jul.2020). Voltarão para a coleção, ou o conflito político entre Ucrânia e Rússia preponderará?

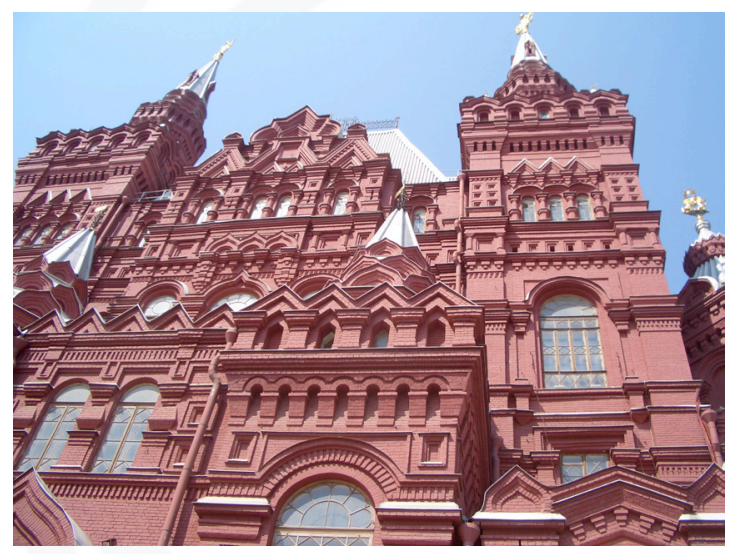

Figura 6: Museu Histórico do Estado. Praça Vermelha. Moscou/RUS. Foto A.29 jul. 2011.

A inação ante a pandemia talvez tenha facilitado ${ }^{10}$ debates candentes sobre a decolonização, a abranger os inúmeros povos que contribuíram para a feição dos

\footnotetext{
${ }^{9}$ Durante a gestão por mim realizada nas Ruínas Engenho São Jorge dos Erasmos/USP, confrontei-me com o obstáculo de se exibir cadáveres, para mim execrável. Situado na Baixada Santista, o primeiro dessa espécie erigido por Martim Afonso de Sousa possui corpos enterrados e que foram pesquisados por especialistas e equipes montadas pelo Museu de Arqueologia e e Etnologia/ MAE USP. A escavação visava examinar as circunstâncias, datar a chacina e divulgar resultados, porquanto observam-se indícios de que não se trata de enterro ritual. Defendi que exauridos os esforços para análise se deveria registrar e fechar aqueles corpos.

${ }^{10}$ Ucrânia pertenceu ao chamado Bloco Soviético até a dissolução deste em 1991. O Governo Russo desde 2014 vem ameaçando apoio e rebeldes ucranianos em oposição ao Governo. Quando das
} 
povos, em todos os sentidos, entre as melhores qualidades do que hoje constituem, a merecer revisão. Tais feições colaboraram para abalos opostos: de um lado o desejo de acesso do público para fruição em instituições; de outro, formas andando em sentido e direção opostos, ao se convencer sobre o respeito às culturas de que provêm.

Entre as notícias mais icônicas em 2020, assinalo o deslocamento de mais de 500 peças rituais, absurdamente denominadas por "Coleção de Magia Negra", abrigadas no Museu da Polícia Civíl do Rio de Janeiro, desde sua fundação (1912) para o Museu da República, na mesma cidade. O nome indica como o preconceito se expressa por nomeação redutora da cultura alheia e elevação da própria. Exigiu três anos de ativismo com lideranças religiosas, política e militância de grupos na campanha “Libertem nosso Sagrado" ${ }^{11}$.

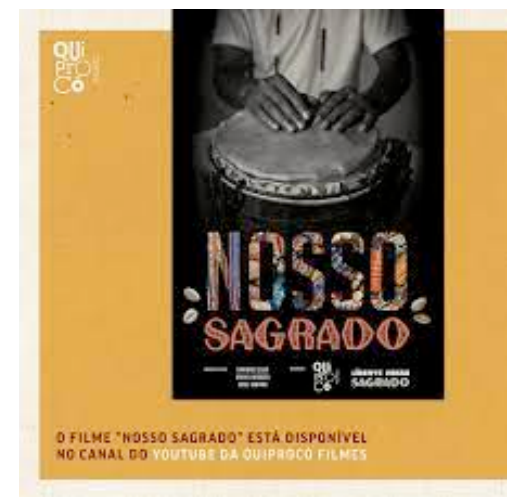

Figura 7: Cartaz do Filme "Nosso Sagrado" direção e roteiro de Jorge Santana, Gabriel Barbosa, Fernando Sousa, produção Quiprocó, Distribuição "Paris Filme". Fonte: Disponível em: https://pages.facebook.com/quiprocofilmes/ Acesso em: 31 maio 2021.

A Polícia Civil do Rio de Janeiro criou, em 1912, o Museu do Departamento Federal de Segurança Pública e a Escola da Polícia. Estendeu-se sua função em 1921 para abrigar o Departamento de Ordem Política e Social (Deops), local este de triste

eleições na Rússia se intensificam as manobras militares, com apoio de países europeus, como França e Alemanha.

${ }^{11}$ A ação "Libertem nosso Sagrado" fez muitos atos e apelaram: ao Instituto do Patrimônio Histórico e Artístico Nacional (IPHAN) para alterar o nome policial, embora não se tenha registro de aceite no site do órgão, até 28.06.2021; recurso no Ministério Público Federal com vistas à liberar as obras; no final de 2017 foi lançado o filme "Nosso Sagrado", que debate a questão. 
marca durante as duas últimas Ditaduras, a de Getúlio Vargas e a civil-militar. Reuniram-se coleções diversas para orientar sobre repressão a estes, desde a formação de novos quadros, refletindo o conjunto de preocupações em cada período, ligados a desvalorizar o Outro, considerando sua espiritualidade como crime. Nesta modalidade, incluem-se armas, objetos referentes ao Partido Comunista, nas ditaduras.

Estudo interessante sobre o movimento "Liberte Nosso Sagrado" reitera que a manutenção, ainda em 2018, revela o esforço necessário, para se superar tais obstáculos coloniais, quando se escravizou grandes segmentos populacionais ${ }^{12}$. A persistência de tais iniciativas deploráveis, após o decreto de fim da Ditadura Militar, como bem acentua a investigação, aqui também persiste violência simbólica histórica “[...] à negritude que custosamente viemos constituindo em nossa história recente de luta pela redemocratização deste país [...] (SANTOS \& BERGER, 2018, p.233).

Conforme divulgam no site do Museu da Polícia, desde 1890 a legislação considerava tal religião na condição de "Crime Contra a Saúde Pública":

Pertence ao Museu da Polícia Civil uma importantíssima coleção constituída por objetos de cultos afro-brasileiros, recolhidos pela polícia no início do século XX, por força da legislação vigente na época e especialmente do art. 157 da lei penal que reprimia "o espiritismo, a magia e seus sortilégios..."13. Reconhecido o valor etnográfico desse patrimônio, foi transferido para o museu e preservado até 1938 , quando o Delegado Silvio Terra requereu ao IPHAN o seu tombamento definitivo.

\footnotetext{
${ }^{12}$ Observei inúmeras notícias relativas ao Século XIX, ora sobre ditos escravos fugitivos, ora sobre apreensão de objetos de culto, ainda no Império, pelo órgão competente. A investigação se deu sob a competente orientação de Aracy Amaral, tendo aprofundado informes reunidos no mestrado concluído na Escola de Comunicações e Artes (ECA) USP sobre o pintor paulista, José Ferraz de Almeida Júnior (1850-99). Os estudos realizados exigiram leitura de jornais, editados em São Paulo e Rio de Janeiro, para poder distinguir mitos e boatos de fatos documentados.

${ }^{13}$ Como se informa no site da Câmara Legislativa, a íntegra do artigo 157 declara-se: "Praticar o espiritismo, a magia e seus sortilégios, usar de talismans e cartomancias para despertar sentimentos de ódio ou amor, inculcar cura de molestias curaveis ou incuraveis, emfim, para fascinar e subjugar a credulidade pública."
} 
Verdadeiramente, obras compõem a esfera criminal: roubam para vender material bruto, como ocorrido no Parque das Esculturas +500 Anos de Brasil, em 30 de novembro de 2020, quando contava com 20 anos de abertura. Trata-se das obras serpente marinha, pelicano e atobás doadas ao município pelo artista, Francisco Brennand, geridas pela Secretaria de Turismo, Esportes e Lazer (Seturel). Veja-se que uma, entre as furtadas nessa oportunidade media $22 \mathrm{~m}$. de altura, no entanto autoridades não conseguiram conter a roubo.

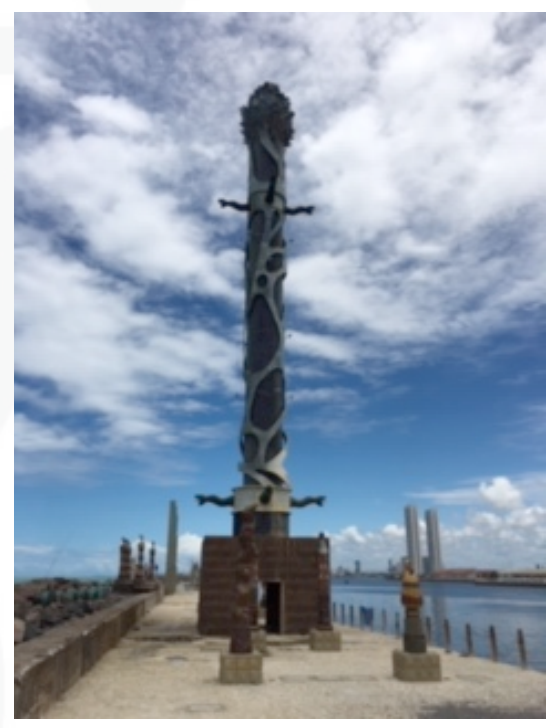

Figura 8: Marco + 500 Anos de Brasil. Recife/PE. Fonte: Foto A. 14 mar. 2020.

\section{(DE)Colonialismo e (DE)Colonialidade}

"O 'colonialismo' não se refere à classificação social universalmente básica que existe no mundo há 500 anos, mas, à dominação político-econômica de alguns povos sobre outros e há milhares de anos anterior à colonialidade. Ambos os termos estão, obviamente, relacionados, já que a colonialidade do poder não teria sido possivel historicamente sem o específico colonialismo imposto ao mundo a partir do final do século XV" (QUIJANO, 2010, p. 26).

O ano de 2000 reacendeu grave debate sobre a retirada de peças de povos originários, exibida como forma reluzente por ocasião da exposição do dito "Descobrimento do Brasil", a gerar cálidos debates. Sublinhe-se a exibição de manto ritual pertencente ao Grupo Tupinambá, depositado na coleção do Museu Nacional da Dinamarca, situado na capital. Note-se ser este um dos seis mantos abrigados em 
instituições européias ${ }^{14}$, privado dessa etnia costeira, espalhada em nosso território, neste caso, requerido por um de seus descendentes, aquele instalado no sul da Bahia, distrito de Olivença/ llhéus.

Agravou-se o rogo, também em 2000, ao se abrir novos setores etnográficos na capital de países colonialistas: Museu Britânico, Museu Dahlem/ALE, enquanto, em 2006, a França inaugurou, o Museu das Artes e Civilizações Não Ocidentais da África, Ásia, Oceania e Américas, nomeado pela localização urbana, Quai Branly. Este com ampla repercussão nos demais e visitação com quantificadores incomuns, na visita de público, além de projeto do renonado arquiteto Jean Nouvel, tendo na parte externa formas geométricas regulares e, no interior, luzes rebaixadas, misto de solenidade teatralizada, luto e rito letal.

Tais iniciativas compõem querelas, já no Século $X V I$, baseadas na defesa de vencedores fundada na autoridade Papal, como o Tratado de Tordesilhas deliberado por este. Abre-se caminho para arrasar crenças nativas, abonada por fé ou pretensa civilidade. Lembro o célebre debate tratado por Immanuel Wallerstein entre Bartolomé de las Casas e Juan Ginés de Sepúlveda, resumido na pergunta: "quem tem direito de intervir, quando e por que?" (2007, p.33). Desde então princípios são alegados, antes religiosos e, no presente, direitos humanos. Inversões de ações e análises se dão também nas próprias culturas, advindas de calamidades naturais, enchentes, queimadas e agora a pandemia.

O Século XX erigiu revisões sobre o papel de distintos povos na imposição de seus postulados e destituição de cultura consolidada por povos originários, como declarou antes o historiador, professor e diretor do Museu Paulista/ USP, Sérgio Buarque de Holanda. Este em sua tese para obtenção de título universitário máximo, defendida em 1958 na USP ${ }^{15}$, utilizou-se de conceito sutil, ao afirmar que os padres

\footnotetext{
${ }^{14}$ Os países, detentores de mantos, de acordo com o divulgado na época são: França, Dinamarca, Itália, Bélgica, Alemanha e Suíça. Teriam sido levados quando os holandeses foram expulsos do Nordeste, no século XVII e não se esclareceu - como se incorporaram aos museus-.

${ }^{15}$ - Tese ocorreu em 1958 e no ano seguinte saiu em livro, a manter o título original.
} 
"incrustaram" no universo local tradições próprias. Ao analisar o terreno entre os dois mundos, o diretor nomeia a criação de "um mito luso-brasileiro", como se verá no caso de Zumé ou Sumé transmudado em São Tomé, na cena catequista (2000, p.133 e 139).

Acrescento que ao se avaliar coleções removidas e a delonga em devolvê-las abordase certo desvio de museus e instituições, no trato do Outro. A desqualificação aponta para suposta ausência de valores, em verdade caros a quem espolia, tidos como superiores, servindo de um redesenho idealizado ante a própria identidade. A operação uniformiza e generaliza simbologias para todo o território a ser rebaixado, ao se alegar a permanência pela falta de segurança e impropriedade no trato. Já as pessoas em geral precisariam ser tuteladas, como narra a criação abaixo de Pagu, muito atual. $\mathrm{O}$ tal outro figura-se como incapaz, pecador, herege e ímpio, devendo estar sob a tutoria clerical.

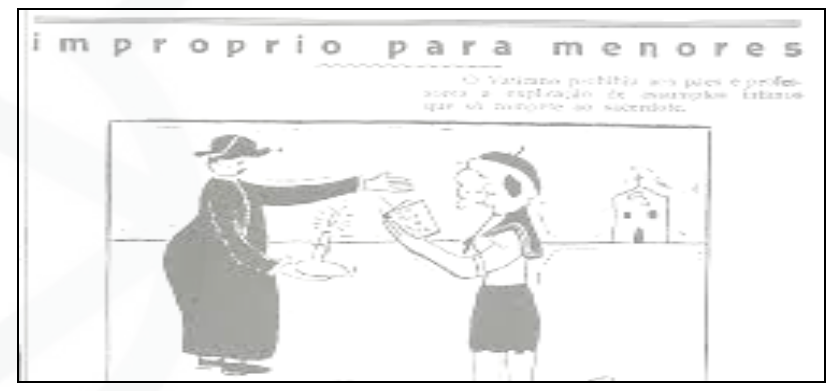

Figura 9: Patrícia Galvão (Pagu). Texto: "[...]- Minha filha, o Papa disse que só o padre pode ministrar educação sexual às crianças". O Homem do Povo. São Paulo, 28 de março de 1931, n. 02, p.01).

Marc Augé lembra, com razão, que a mundialização da cultura, ao final do século passado, erigiu imagem idealizada do que se deseja ser, assim negando alteridades, isto ajudado pela difusão de meios digitais. Observe-se que as mídias sofrem avalanche de caras e bocas deslumbradas, parecendo belas, elegantes, realizadas e felizes. Augé assinala o domínio de estereótipos criados sobre como "[...] devem ser o homem e a mulher livres, o corpo verdadeiramente em forma e a vida verdadeiramente feliz" (1999, p.104-5). 
As posturas de incrustar valores, crenças e dissimulações há muito têm sido ativadas no que hoje se denomina América Latina. Insere-se na colonialidade do poder como bem assevera Anibal Quijano. Mandatários, reis, aventureiros, clérigos ou colonizadores engendraram versões para assegurar sua atuação na chancela de superior, ilibada e abençoada, visando fazer valer princípios próprios, tentar dissimular apagamento e sobrepor-se. O mecanismo agrada aos que os protegem e isto se constata em inúmeros confrontos.

Veja-se a chegada de padres Jesuítas nos vários continentes e, em particular, em nosso, quando adotaram medidas para subestimar e eliminar a cultura da civilização local, ante as inúmeras etnias ativas nele. O choque colaborou para prestigiar iniciativas doutrinárias. Ensinaram dogmas, postulados e lendas por meio de hinos, contos, encenação, ritos, edificações, traçado urbano e narrativas, em que pese dificuldade com a língua. Contudo a tal erudição, com os pés no renascimento humanista, nada significou para aproximá-los aos povos, estando as iniciativas concernente apenas aos europeus aqui estabelecidos. Por outro lado, imagine-se o quanto nudez, mitos, cerimônias, poligomia, celebrações e hábitos colidiam com suas certezas clericais, sonho de lucros, dominação e padrões tidos como um bem universal.

A empreitada poderia acenar na disseminação de formas ideais elevadas, para alguns, não obstante, cifras e trabalhadores submissos seria um foco mais real e os europeus não subsistiriam sem o labor e o saber local ${ }^{16}$. Hipótese de que a união mista entre europeus, índios e africanos abrandaria as relações hostis não se aferiram, ao contrário. Como bem alude Gruzinski, em relação ao atual México, a imensa mescla entre estes pouco contribuiu para o dirimir diferenças ou o fosso social evidente. "A nova sociedade urbana fabricava quantidade de excluídos, que

\footnotetext{
${ }^{16}$ Observe-se que em 1553 o vice-rei Luis de Velazques inaugura, no atual México, a primeira universidade, claro que beneficia tão somente seus pares.
} 
respondiam com a violência à repressão [...] e a todas as formas de dominação colonial” $^{17}(2004$, p.340).

Com vista a adaptar seu ideário ao existente na Civilização Tupi-Guarani, os frades se apropriaram de narrativas locais para a lida doutrinária, a nortear a própria vida e fundada na hoje nomeada, religião Católica. Para Homi K. Bhabha o discurso colonial tentou garantir o jogo no sistema de poder e definir o colonizado "[...] como uma população de tipos degenerados com base na origem racial de modo a justificar a conquista e estabelecer sistemas de administração e instrução" (1998, p.111).

Outro aspecto que Bhabha sustenta diz respeito a um valor habitual formulado em ações discriminatórias até a atualidade, ou seja, o mito da origem histórica. Esclarece que o estereótipo dominado por certos aspectos, a saber:

\begin{abstract}
0 mito da origem histórica - pureza racial, prioridade cultural produzido em relação com o estereotipo colonial tem a função de 'normalizar' as crenças múltiplas e os sujeitos divididos que constituem o discurso colonial como consequência de seu processa de recusa" (1998, p.115).
\end{abstract}

Postura em contraste e digna de nota, se observou, no início do século passado, com os modernistas atuantes na Europa em busca de renovação visual, sintonizados à redefinição de preconceitos criaram um espaço entre, no contato com soluções vanguardistas. Alguns artistas dispunham de recursos para visitar museus etnográficos, no e fora do país e valeram-se da chance para atualizar a imagética em diálogo com a linguagem de povos originários, antes tida como primevas. Veja-se a produção, nos Anos de 1920, de desenhos, máscaras e figurinos sobre lendas, crenças e talismãs realizadas por Vicente do Rego Monteiro, reunidas também em livro e reeditada em edição facsimilar primorosa pela Editora da Universidade de São Paulo.

\footnotetext{
17 "La nueva sociedade urbana fabricaba cantidad de excluídos, que respondían con la violência a la represión [...]y a todas las formas de dominacón colonial. Trad. A.
} 


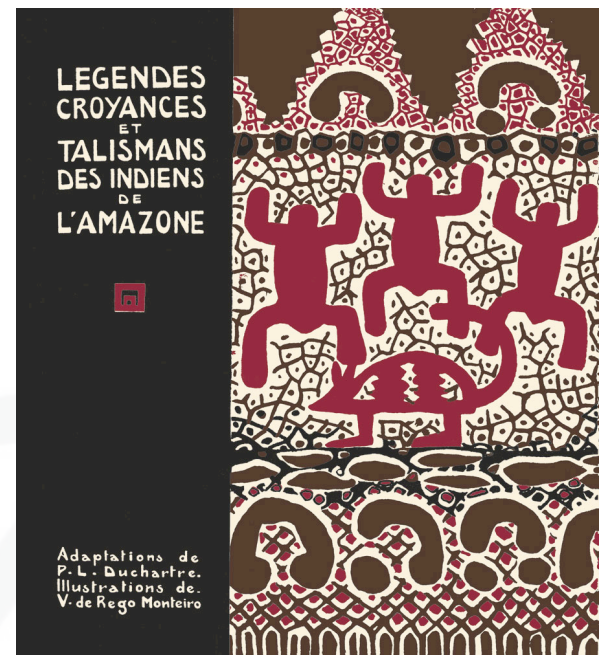

Figura 10: Vicente do Rego Monteiro. Livro Fac-similar "Lendas, crenças e talismãs dos índios da Amazonia.São Paulo: Edusp, 2015, Fonte: https://www.edusp.com.br/livros/do-amazonasa-paris/ Acesso em:20 maio 2021.

Ilustra bem a transmutação de narrativas e a busca de algo comum, entre os povos nativos e o cristianismo, as muitas lendas sobre a presença de São Tomé nesta terra. Contadas por vários catequistas, a incluir os padres jesuítas, José de Anchieta e Manuel da Nóbrega. O relato reforça doutrinas e finalidades incomuns da religião não apenas neste território, mas, para outros na atual América Latina. Os detalhes foram documentados em cartas pelo padre Nóbrega, em 1549, reiterada em 1584 por Anchieta, transformando o santo peregrino em Sumé ou Zumé dos povos iniciais. Seria um homem branco e teria chegado antes de Pedro Álvares Cabral ${ }^{18}$.

A história colhida pelo padre Nóbrega, se documenta em carta de 15 de abril de 1549, sublinhando ser proveniente de fonte fidedigna: “[...] as raizes de que cá se faz pão, que São Tomé as deu, porque cá não tinham pão nenhum. E isto se sabe da fama que anda entre ele, sobre plantio e manejo da terra" (LEITE,1954, p.117 v.I). Com vistas a validar o fato, ele alude à pueril fala de que seriam dele os pés gravados em pedras, em São Vicente/SP e na Bahía.

\footnotetext{
${ }^{18}$ Conjunto significativo de viajantes foi pesquisado pioneiramente por Ana Maria Belluzzo, professora da FAU USP; já o mito de São Tomé foi registrado, entre outros, por Filipe Moreau.
} 
De forma análoga, padre Anchieta aborda o tema em "Informações do Brasil e de suas Capitanias" (1584), sobre a passagem de São Tomé nos primórdios do Cristianismo em missão pedagógica e a serviço da difusão religiosa. No entanto, altera ao narrar que os nativos citam boas obras de Tomé "[...] mas não se lembram em particular de nada" (MOREAU, 2001, p.268). Nóbrega acentua o saber e poderes raros, como abrir as águas para fugir de flechas, lançando-as para os que o atacavam, assim heroicizando Tomé. Já Anchieta reforça o mito e salienta andanças catequizantes por territórios.

Como bem alude Alfredo Bosi "[...] os missionários fizeram uma partilha tática no conjunto das expressões simbólicas dos nativos" (1992, p.68). Colheram e retiveram das histórias correntes só aquelas passagens míticas nas quais apareciam entidades cósmicas (Tupã), ou então heróis civilizatórios (Sumé), capazes de se identificar, com as figuras bíblicas de um Deus Criador. Ao que se sabe, na leitura dos amplos registros de viajantes e pregadores, os tupis não prestavam culto a deuses e heróis, tal tática teria ensejado aos jesuítas interferir no universo simbólico dos povos originais, com as certezas do catolicismo. (1992, p. 68). Observa-se então a junção de um plano espiritual ao político, de modo a consolidar o poder luso-espanhol nas Américas.

\section{CONFLITOS E O OUTRO}

"A alienação do espectador em proveito do objecto contemplado (que éo resultado da sua própria atividade inconsciente) exprime-se assim: quanto mais ele contempla, menos vive; quanto mais aceita reconhecer-se nas imagens dominantes da necessidade, menos ele compreende a sua própria existência e o seu próprio desejo. (DÉBORD, 2005, p.19).

Reitere-se as declarações na presente epidemia, dotadas de ações espetaculares veiculadas de forma célere e em escala incomum. Merecem análise crítica sempre com o objetivo de se entender o porquê, em quais circunstâncias, em que cenário e mesmo trajes, cores e postura utilizadas nos bastidores da cena. Demarca-se a diferença identitária em que se tenta persuadir sobre dada elevação no saber de alguns, para assuntos complicados, como o da pandemia. Efeitos e luzes cooperam para convencer sobre a veracidade, propriedade e capacidade em responder dúvidas 
inomuns, que exigem reflexão. Vejam-se a penetração de notícias falsas e não apenas no país, a influenciar eleições em muitos países.

Guy Débord (1968) alerta o quanto um espetáculo torna-se caminho para alienação, logo é imprescindível tentar ir além das aparências reluzentes, falas retóricas e informes oficiais para se vislumbrar interditos. Eventos ganham visibilidade em cenas montadas e soluções, que pululam no cotidiano das redes. Como antes bem aduziu ao alertar sobre cenas, em que dominam: "[...] condições modernas de produção, se anuncia como uma imensa acumulação de espectáculos. Tudo o que era directamente vivido se afastou numa representação" $(2005$, p.8).

Igualmente, antes mesmo da epidemia ativistas e artistas apontaram ações midiáticas de patrocínio em museus e outros órgãos com ampla visibilidade, após desastres ambientais e humanos, por estas provocados. Inúmeros membros pensantes negavam-se a respaldar atos controversos na fabricação de produtos, sob máscara beneficente de amparo cultural, nos Estados Unidos e Europa. Entre tantas reações, o alvo maior foram as petroleiras ${ }^{19}$ inglesas, na devastão de grandes áreas marinas, mas também no fabrico de fármacos capazes de viciar, dissipar manifestações, ou poluir.

Criou-se o movimento Art Not Oil Coalision, ativo quando contrato seria reativado e na pandemia (2020). Pressionaram o congresso a iniciar petição para que se promulgasse veto definitivo de suporte financeiro à cultura. Contrapuseram-se também à doação de obras, fundos e patrocínio em mostras, enfim, desnudaram ícones estelares no mundo do espetáculo.

\footnotetext{
${ }^{19}$ Noticiado (2015) em ampla escala, o protesto em Londres/ING contra o apoio por 5 anos da British Petroleum, (c. de 13,6 milhões de euros), após vazar o produto no Golfo do México, a abranger: Museu Britânico, Tate Modern, Galeria Nacional de Retrato e Royal Opera House.
} 


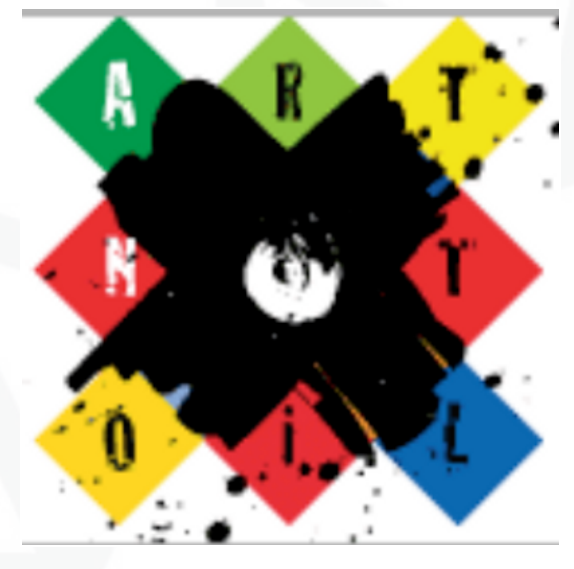

Figura 1 Logotipo do movimento Art Not Oil Coalision. Fonte: https://twitter.com/ArtNotOil/photo/ Acesso em:25 jun. 2021

Stuart Hall contribuiu de forma decisiva no debate quanto à questão identitária como algo flutuante e plural, não raro espelhado pelo que não somos, o tal outro, o que lhe valeu o título de criador do multiculturalismo, como se viu, criticado por Guasch, para ela, dada a ausência de ênfase na troca. Ressalto que Hall chama a atenção como a discurso daqueles detentores de lugar de fala, no caso do colonialismo europeu, resultaram em assimilação de tal identidade em partes de territórios invadidos. Os objetos retirados de dada cultura, prometidos para repatriamento inserem-se nesse quadro complexo de reconquista simbólica, por meio de objetos e corpos.
A identidade surge não tanto da plenitude da identidade que já está dentro de nós como indivíduos, mas uma falta de inteireza que é preenchida a partir de nosso exterior, pelas formas através das quais nós imaginamos ser vistos pelos outros (HALL, 2006, p. 39).

A ênfase em se debater deu frutos e vários países colonialistas viram-se instados a devolver obras salvaguardadas, sentindo-se ameaçados. Alegam direito obtido por luta e papel civilizatório, antes mesmo da pandemia. Entre as juras sobre quanto à devolução e repatriação, a serem seguidas para se aferir efetividade, realço a do então recém-eleito presidente francês, Emmanuel Macron, em visita à Burkina Faso/ AFR, no final do ano de sua posse (2017), que decidiu se dirigir a esse território. Analistas entenderam o gesto, como reconquista comercial com a África, em combate à prevalência da China. 
Macron em preleção na Universidade Uagadugu, divulgou o intuito em devolver bens musealizados. Assim, em cinco anos, para ele reuniriam-se condições plenas “[...] para restituição temporária ou definitiva do patrimônio africano para África" ${ }^{20}$. Levanta uma questão dúbia: seria temporária ou definitiva, em vista de que há imenso conjunto africano em museus francês, em especial no Museu das Artes e Civilizações da África, Ásia, Oceania e América (MACAAOA), situado no Quai (Cais) Branly em Paris, obra do arquiteto Jean Nouvel (2006), para marcar a presidência de Jacques Chirac.

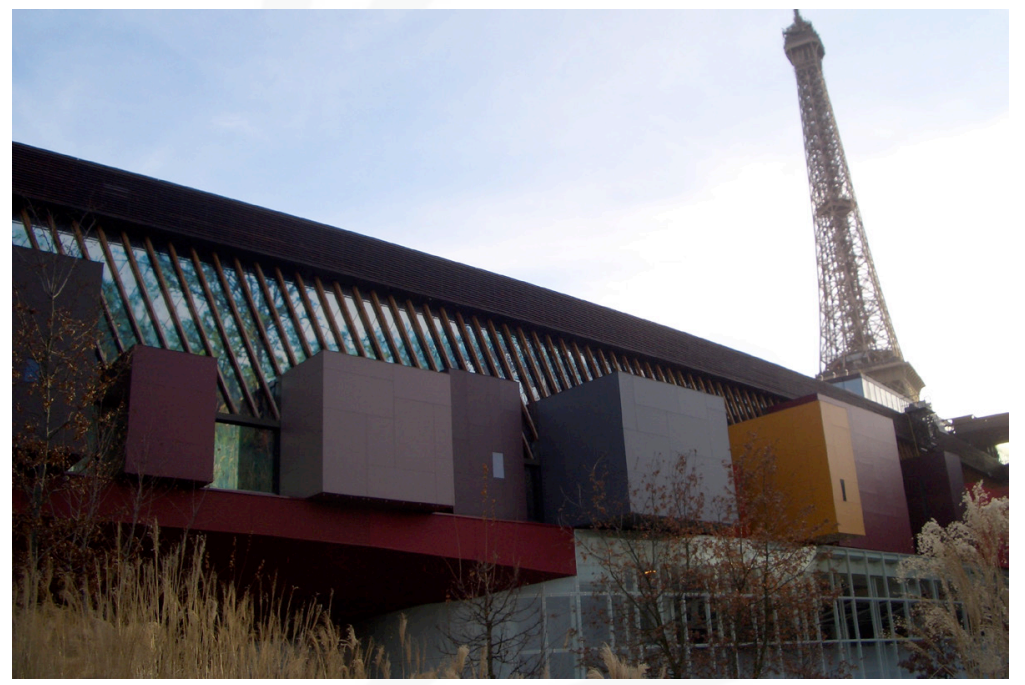

Figura 12:. Jean Nouvel (2006). Museu Museu das Artes e Civilizações da África, Ásia, Oceania e América. Fonte: Foto A. 25 jan. 2008.

Provavelmente, visando credibilidade, Macron confiou estudo sobre origem das peças africanas nos museus a uma dupla engajada na devolução: o professor, economista e o escritor senegalês Felwine Sarr e a historiadora francesa Bénédicte Savoy. Esta acabara de pedir demissão de projeto, a merecer exame, por lidar com a questão de decolonização, o Humboldt Forum de Berlim, alegando obstáculos para efetivar pesquisa sobre origem. Esta reside em dialogar e levantar provas para aferir se tratar de compra, presente ou ilícito. Em novembro (2018) entregaram o requerido, com o título: "Restituir o património africano: para uma nova ética relacional".

\footnotetext{
${ }^{20}[. .$.$] pour des restitutions temporaires ou définitives du patrimoine africain en Afrique" (Trad. A.).$
} 
Além de rever a catalogação e separar as obras de várias etnias africanas, formularam projeto de "ética relacional", que se encontra no título. Assinalam que a pesquisa de origem se torna fulcral, quando em diálogo para cotejar se foram obtidas por atos colonialistas: de um lado via forma ilícita, violenta, roubo, pilhagem; mas também, para discernir e acatar o sentido essencial e usual para dado povo. Ademais apreciam objetos não em seu valor de mercadoria rara e bela, mas sim, na chave de intermediários, portadores de usos, costumes, cultura de grupos, em diálogo com o Outro, a saber:

Os objetos são mediadores de correspondências, metamorfoses e passagens em ecossistemas caracterizados pela fluidez e circularidade. Em um universo reticular, eles são os operadores de uma identidade relacional e plástica, cujo objetivo é participar do mundo e não dominá-lo (SAVOY \& SARR, 2018, p.29) ${ }^{21}$.

Reações se deram em plena vaga da Covid-19, sejam as negações do Museu Britânico, sobre repatriar coleções coloniais, seja sobre inauguração, em Berlim/ALE do Humboldt Forum, resposta milionária alemã ${ }^{22}$ de órgão com mostras etnológica e antropológica. Reúne aquelas nativas de Ásia, África, Américas e Oceania, como o Quai Branly e o Britânico. Imediatamente sofreu vários ataques, em especial na política, sob acusação de tentativa para apaziguar o passado colonialista, desviar o foco candente advindo do Holocausto, também, daquele passado cindido, pelo Muro, que cai em 1989. O historiador Jürgen Zimmerer, da Universidade de Hamburgo, reiterou o fato em declarações para várias mídias, lembrando que há cabeças humanas musealizas em outros órgãos alemães.

Cabe especificar entre as polêmicas ante a localização: o lugar antes abrigou o Palácio da Cidade de Berlim (Berliner Stadtschloss), atacado na II Guerra Mundial e depois destruído, no que antes fora o lado Oriental. Funcionou ali o chamado

\footnotetext{
${ }^{21}$ Les objets sont des médiateurs de correspondances, de métamorphoses et de passages dans les écosystèmes caractérisés par la fluidité et la circularité. Dans un univers réticulaire, ils sont les opérateurs d'une identité relationnelle et plastique, dont le but est de participer au monde et non de le dominer" (Trad. A.).

${ }^{22}$ Informes divulgados por várias mídias sobre o orçamento dão conta de que teriam sido gastos mais de 600 milhões de euros e, note-se, em continuidade na época de pandemia.
} 
Parlamento da República Democrática Alemã (1949-90), destruído em 2008. A escolha de se estabelecer exatamente nesse espaço o Humbolt Forum marcaria um desvio de amplo debate fixado em livros, filmes, museu, entre tantos, sobre o genocídio praticado no Holocauto, durante a Guerra?

Outro aspecto decorreu da opção de um projeto no edifício em espécie de colagem, feita pelo arquiteto Franco Stella. Uniu diversas citações do passado, talvez para acalmar ânimos, entre estas, a cúpula, algumas fachadas internas e do pátio, tendo mesclado com novas. Após reações adversas, manteve na cúpula alusões cristãs, a desconsiderar as demais religiões daquele território; além da cruz a inscrição, que alude ao fato de que se deve ajoelhar diante de Jesus: "Não há outra salvação, não há outro nome dado aos homens, mas o nome de Jesus, em homenagem ao Pai [...]" (Deutsche Welle Brasil, 2020).

Observe-se que apenas em janeiro de 2021 divulgou-se a reabertura, porém sem público e em espetáculo online, dada a pandemia, com a coleção do Imperador Leopold $\mathrm{II}^{23}$. Do próprio Fórum, o conselheiro, George Abungu, ex-diretor-geral dos Museus Nacionais do Quênia remeteu carta à chanceler Angela Merkel, divulgada com ressalto em mídias. Em um dos trechos Abungu sublinha a acuidade em se devolver aquela parcela de artefatos possuidores de "[...] - significados simbólicos e ritualísticos - que foram saqueados. Estes precisam retornar para o lugar de origem." (KUSHNER, 2021).

A declaração delineia uma via conceitual para saída de museus, ao contrário de outra visionária, ou seja, repatriar todo e qualquer objeto, a par de se tomar decisões partilhadas com os povos. Savoy então (2021) reafirmou ser contrária e imprópria a abertura do Humboldt Forum, sem catalogar origem, prática corrente em museus etnológicos e, mais, em palácio colonial ${ }^{24}$, quando, para a historiadora, a Alemanha

\footnotetext{
${ }^{23}$ Leopold II (1740-92) obteve múltiplos títulos políticos, daí o conjunto de sua coleção. Como se consagrou, foi Sacro Imperador Romano, Rei da Hungria e Boêmia, Arquiduque da Áustria, e GrãoDuque da Toscana no final da vida.

${ }^{24}$ Assinale-se que, nesse Palácio, no início do Século XX, o Imperador Guilherme II, em conflito com colônias africanas determinou o genocídio dos povos, Herero e Nama.
} 
mostra atitude ressaltável ao abrir seu território para receber imigrados vindos de diversos locais.

Na França e na Holanda, em 2020, as ações geraram reações incisivas de ativistas congoleses, ligados à Organização Yankanku, ao tentar restituir peças de seu povo, citando ser ato colonialista e indevido, atraindo atenção, em nome da causa e ao que nomearam, pilhagem europeia (CARVALHO, 2020). Preocupação se deu também na Holanda, segundo se veiculou, ao designar comitê, que orientou a restituição total do acervo retirado de países como Indonésia e Suriname (FERRER, 2020). Vale acompanhar!

Na África, por exemplo, após a Independência do Zaire em 1973, se realizou uma restituição incomum, de obras mantidas no Africa Museum, em Tervuren/ BEL, sob protestos, citando que lá estariam sob cuidado especial. Mas, além de peças havia corpos e devolvê-los se constitui em gesto notório e decisivo. Assim, Nelson Mandela, logo após sua posse (1997) exigiu devolução da França de restos mortais da africana Sarah Baarman, falecida em 1815 e tendo partes, como cérebro e órgãos sexuais, exibidos em Paris, no Museu do Homem, até 1974. Apenas em 2002 houve a restituição (PARKISON, 2016).

Exibir humano tido por exótico não reside em prática recente e cabe lembrar o deplorável conjunto vivo de povos originários vindos de colônias, apresentados na Exposição Universal de Paris em 1889, nomeado por Village Nègre. Nessa época graçavam teorias racialistas no Velho Mundo, uma vez mais, para tentar provar a elevação européia. Cientistas vindos ao país no Século XIX prestavam suporte e serviços a essa causa, ao se aproximarem dos povos originários.

Por outra parte há cabeças, tsantsas, de inimigos encolhidas por povos da Amazônia, que se acham em museus. O Brasil teria proposto repatriamento como Mandela? Este acervo humano cooperaria para ampliar o saber relativo à cultura local? Ilustra esta última questão decisão ocorrida em Oxford/UK, junto ao Museu Pitt Rivers, em setembro de 2020, que resolveu retirar de exposição cabeças humanas. Declarações da diretora, Laura Van Broekhoven residiririam em não mais interpretar tais povos no 
sentido negativo, em entrevista ao jornalista Pablo Uchoa, nesse mesmo ano pela BBC Brasil.

As cabeças eram uma das maiores atrações do museu, mas em vez de fornecer uma compreensão mais profunda sobre outras culturas, elas estavam reforçando estereótipos sobre esses povos serem 'selvagens', 'primitivos' ou 'horriveis'.

Não menos sofrível foram os chamados "exposições coloniais", em que pessoas de povos originários enjauladas eram exibidas, isto desde o século XIX e por mais de um século. No Brasil em 1882 D. Pedro II abriu, no atual Museu Nacional, uma mostra de sete indígenas ao vivo, nomeada Exposição Antropológica Brasileira, em sintonia com o costume e enorme adesão de visitantes. Em estudo sobre o tema, Marina Cavalcante Vieira afirma sobre a exposição que "[...] os Botocudos representavam por definição o 'outro" antropológico, a imagem que espelha exatamente o contrário do Brasil civilizado" (2019, p. 352).

\section{CONCLUSÃO}

Formas ligadas à identidade dos povos têm sido alvo para ataques de territórios em conflito. Desde monumentos até peças destinadas a culto religioso vêm sendo destroçados, pilhados, apartados de seu local original e expostos como representação de força. Parecem conter nas entranhas significados simbólicos indicativos de triunfo, orgulho, superioridade, poder, dominação, ou demais sentimentos rasteiros de um povo contra outro. Em paralelo, objetos surrupiados de povos e em distintas guerras, decorrido certo tempo, quando obras subterrâneas ocorrem, emergem da terra.

Neste estudo, procurou-se focar em casos exemplares museais, a sonhar com nova forma para se atuar com bens culturais do Outro. No presente, exigem estratégia para driblar a falta de público, fruição via live, filmes, falas explicativas; exploração de ícones da coleção. Critico esta última, por apontar para fetiche, comentário diretivo de ditos peritos e pergunto: seria momento oportuno para se enfrentar outro conteúdo? 
Mais grave, enfatizo fatores deploráveis, ainda ativos: rebaixar o Outro a uma tela vazia; elevar curador a mago; reduzir a cultura material à condição de preciosa; entender o saber como distintivo de classe. Fica a dúvida: quais as inovações cunhadas para este tempo? O que criação e pesquisa originaram para baseá-las? Será que apenas se repetiu ad nauseam espetacularização midiática e promocional de egos colosso, ficando-se apenas no antes aclamado, visto, memetizado, viralizado?

Ante robustos obstáculos em 2020, museus reagiram e buscaram saídas em diálogo, seja compartilhando oficinas e apresentações públicas, a partir de inventividade e prontidão, ainda que padecendo com redução de seu quadro. Erigiram-se formas para encarar com vigor a Covid-19, criando "Planos de Gestão, Crise e Risco" no coletivo, discutindo postulados e redesenho pactuado com novos interlocutores, em especial no ICOM. Desta maneira cintilaram questionamentos, valores, ligados a grupos favorecidos e ampliação de identidades entre origens, ou seja, miscigenadas e não apenas as locais.

Tal postura favorece ampliar declarações genéricas e universalistas sobre valor e incorporação, ou não, de acervo perto ou longínquo, para além do que se encontra firmado e consagrado. Cabe sempre inquirir, ao se encarar novas peças museais: o que, de quem, onde, como, por que, para que, para quem, ou seja: o que é sua essência; memória de quem; raridades provenientes de onde e como se obteve; por que reduzi-las a cenário de espetáculo; além dos pares, ações alcançam os inabituais do órgão?

Interessou analisar reversões de conjunturas adversas durante a pandemia relativa à Covid-19, no campo da decolonização de coleções, preservação compartilhada em institituições e nas artes em geral. Sublinhe-se que a demanda por isolamento desgastou limites para outros focos, inúmeras culturas e expressões, ante o total aviltante de vidas perdidas; a nefasta crise social, política, sanitarista educacional e ambiental, demanda por isolamento. Chamou a atenção, uma vez mais, como expressões artísticas podem ser essenciais para pulsar crítica, harmonia, união, ainda que à distância. 
Nesta era e nas boas versões, museus puderam rever certezas, fornecer conteúdo, quando pessoas devem ficar em casa, diversificando em caminhos inéditos e múltiplas atividades. Esgarçou-se o limite na atuação convencional em presença e esse órgão já não se reduz ao senso comum, não raro, ainda tido na faixa de guardião da memória, colecionador de belas raridades e local para diversão, cifras, show, espetáculo e deleite.

Demandas sociais avivadas por ativismo seguem na atual tendência em se convocar etnias distintas para assumir cargos, suavizar a imagem, nos vários âmbitos preservacionistas, ainda privilegiando o desgastado, "politicamente correto". Seriam, por vezes apenas algo de marketing para atrair mídias? Ao contrário, no lugar do espetáculo, caberia aos órgãos assumir liderança para trazer seus semelhantes no centro decisório, assim, contribuirão para fugir do paternalismo, em que domina o fazer para, ou por alguém? Ao reflorescer as luzes e ações aguardam-se renovações, continuidade, trocas, quem sabe um tributo à vida. Ciça, Inverno 2021.

\section{BIBLIOGRAFIA CITADA}

ANDRADE, Oswald. GALVÃO, Patrícia; LIMA, Queiroz. O Homem do Povo. Março/abril, 1931. Facsimilar com introdução de Augusto de Campos. São Paulo: Imprensa Oficial do Estado: Arquivo do Estado, 1984.

BELLUZZO, Ana Maria. O Brasil dos Viajantes. São Paulo: Metallivros, 1994.

BOSI, Alfredo. Dialética da colonização. São Paulo: Companhia das Letras, 1992.

CHARTIER, Roger. A história cultural: entre práticas e representações. Lisboa: Difel; 1990.

DE CERTEAU, Michel. A Invenção do Cotidiano, 4 ed. Petrópolis: Vozes, 1999.

DÉBORD, Guy. A sociedade do espetáculo. Lisboa: Edições Antipáticas, 2005.

GUASCH, Anna Maria. La memoria del Outro en la era do global. Santiago do Chile: Museu Nacional de Bellas Artes, 2010.

HALL, Stuart. A identidade cultural na pós-modernidade. Rio de Janeiro: DP\&A, 2006.

HOLANDA, Sérgio Buarque de. Visão do Paraíso: os motivos edênicos no descobrimento e colonização do Brasil. São Paulo: Brasiliense/ PubliFolha, 2000. 
KOSELLECK, Reinhart. Estratos do tempo: estudos sobre história / Rio de Janeiro: Contraponto: PUC-Rio, 2014.

LEITE, Serafim S.J. Cartas dos dos principais jesuitas do Brasil. São Paulo: Comissão do IV Centenário da cidade de São Paulo, 1954.

LOURENÇO, Maria Cecília França. Museus Acolhem Moderno. São Paulo, EDUSP, 1999.

MOREAU, Filipe E. Os índios nas cartas de Nóbrega e Anchieta. São Paulo: Anablume, 2001.

WALLERSTEIN, Immanuel. O Universalismo Europeu: a retórica do poder. São Paulo: Boitempo.

Fontes eletrônicas e sites

ART FORUM. France to return artifacts to Benin and Senegal within a year,.2020. Disponivel em: https://www.artforum.com/news/france-to-return-artifacts-tobenin-and-senegal-within-a-year-84313 Acesso em: 23 mar. 2021.

ART NOT OIL COALISION. Disponível em: https://twitter.com/ArtNotOil/photo/ Acesso em 25 jun. 2021.

BHABHA, Homi K. O local da cultura. Belo Horizonte: EUFMG, 1998. Disponível em: https://edisciplinas.usp.br/bhabha-homi-k-o-local-da-cultura.pdf/ Acesso em: 26 jun. 2021

CÂMARA dos Deputados. Legislação. Decreto 847 de 10 de outubro de 1890. Capítulo III. "Dos crimes contra a saúde pública. Disponível em: https://www2.camara.leg.br/ Acesso em: 26 maio 2021.

CARVALHO, Bruno Amaral de. Viva a àfrica Livre: ativistas tentam recuperar obras africanas em museus na Holanda. 20 set. 2020. Disponível em: "Viva África livre". Ativistas tentam recuperar obras africanas de museu na Holanda (wort.lu). Acesso em 19 abr. 2021.

CHENU, Isabelle. Quem roubou quem? França quer multar ativistas que tentaram conficar peças africanas de museu em Paris. Paris: Radio France Internacionale Brési, 20 set. 2020.I Disponível em: https://www.rfi.fr/br/frança/20200930quem-roubou-quem-frança-quer-multar-ativistas-que-tentaram-conficarpeças-africanas-de museu-em-paris/ Acesso em 12 abr 2021

CONVENÇÃO para a Proteção do Patrimônio Mundial, Cultural e Natural. Disponível em: https://whc.unesco.org/archive/convention-pt.pdf/ Acesso em 27 abr. 2021.

CÚPULA do Palácio no coração de Berlim gera polêmicas. Deutsche Welle Brasil 29 maio 2020. Disponível em: https://www.dw.com/pt-br/cúpula-de-palácio-nocoração-de-berlim.../Acesso em: 31 maio 2021. 
EM LIVE Marcos Ponte chama corte em orçamento 2021 de 'estrago'. Disponível em: https://www.metropoles.com/brasil/economia-br/em-live-marcos-ponteschama-corte-em-orcamento-de-2021-de-estrago/ Acesso em: 28 abr. 2021.

FERRER, Isabel. Holanda contempla la devolución incondicional del arte colonial: Un informe oficial abre la puerta al retorno de 450.000 piezas. Disponível em: https://elpais.com/cultura/2020-10-17/holanda-contempla-la-devolucionincondicional-del-arte-colonial.html/ Acesso em 20 maio 2021

FRANÇA e África uma separação em câmara lenta. Deutsche Welle (DW), Berlim. Disponível em: https://www.dw.com/pt-002/fran\%C3\%A7a-e-\%C3\%A1fricauma-separa\%C3\%A7\%C3\%A3o-em-c\%C3\%A2mara-lenta/a-54404342 Acesso em 12 maio 2021.

GRUZINKI, Serge. A águia e o dragão: Ambições européias e mundialização no século XVI. São Paulo: Cia. Das Letras, 2015. Disponíovel em https://edisciplinas.usp.br/pluginfile.php/1914041/mod_resource/content/1/ GRUZINSKI_2015.pdf/Acesso em: 28 jun. 2021

-------La ciudad del México: una história. México: FCE, 2004. Disponivel em: https://edisciplinas.usp.br/pluginfile.php/5120604/mod_resource/content/1/ GRUZINSKI_2014.pdf/ Acesso en 26 jun. 2021.

O historiador, o macaco e a centaura: a 'história cultural' no novo milênio. Estudos Avançados, São Paulo v.17, n.49, p.23-60 set-dez 2003. Disponível em: https://www.revistas.usp.br/eav/article/view/9960/11532/ Acesso em 3 fev. 2020.

https://edisciplinas.usp.br/pluginfile.php/5120604/mod_resource/content/1/ GRUZINSKI_2014.pdf/

INTERPOL divulga lista de obras de arte mais procuradas no mundo. Disponível em: https:///www.portal.iphan.gov.bder/noticias/talhes/5735/ Acesso em 28 jun. 2020.

KUSHNER, Jacob. Na Alemanha, novo museu reacende uma polêmica colonial. Londres: National Geographique Brasil. 12 jan. 2021. Disponível em: https://www.nationalgeographicbrasil.com/historia/2021/01/na-alemanhanovo-museu-reacende-uma-polemica-colonial/ Acesso em 13 fev. 2021.

MONTEIRO, Vicente do Rego. Lendas, crenças e talismãs dos índios da Amazonia. (Capa) São Paulo: Edusp, 2015, Fonte: https://www.edusp.com.br/livros/doamazonas-a-paris/ Acesso em: 20 maio 2021.

MUSEU da Polícia Civil do Estado do Rio de Janeiro. Disponível em: http://www.policiacivilrj.net.br/museu.php/ Acesso em: 26 maio 2021.

PARKINSON, Justin. Sarah Baartman: a chicante história da africana que virou atração de circo. Em 11/01/2016. Disponível em: Sarah Baartman: a chocante história 
da africana que virou atração de circo - Agência Patrícia Galvão (agenciapatriciagalvao.org.br)/ Acesso em: 24 maio 2021.

PETITION to Parliament to ban fossil fuel sponsorship. Em 02.06.2021. Disponível em: https://artnotoil.org.uk/ Acesso em 25 jun. 2021.

PINTO, Flávia da Silva \& BERGER, William. Libertem nosso Sagrado: Violência e Intolerância Religiosa no caso das peças sagradas das religiões de matrizes africanas no Brasil (1889-2018). In: Musas/Musas/ Revista Brasileira de Museus e Museologia/IPHAN. No. 8 de 2008. Disponível em: https://www.museus.gov.br/wp-content/uploads/2018/10/revista-musasn8.pdf/ . Acesso em: 27 maio 2021.

QUADRO de devoluções concretizadas. Fonte: UNESCO. Disponível em: http://www.unesco.org/new/fr/culture/themes/restitution-of-culturalproperty/committes-successful-restitutions/ Acesso em: 12 maio 2021

QUIJANO, Anibal. Colinialidade, poder, globalização e democracia. Revista Novos Rumos. Unesp Marília/SP 2002 (37): 17, p.26. Disponível em: https://revistas.marilia.unesp.br/index.php/novosrumos/article/view/2192/18 12/ Acesso em: 27 abr 2021.

SARKIS, Hashim. Leão de Ouro especial para Lina Bo Bardi. Disponível em: https://www.labiennale.org/en/architecture/2021/17th-internationalarchitecture-exhibition / Acesso em: 21 de maio de 2021.

SARR, Felwine \& SAVOY, Bénédicte. Rapport sur la restitution du patrimoine culturel africain : Vers une nouvelle éthique relationnelle. Paris: Ministere da la Culture et Université Paris Nanterre, 2018. Disponível em http://restitutionreport2018.com/sarr_savoy_fr.pdf/Acesso em: 13 abr. 2021.

UCHOA, Pablo A mórbida coleção de cabeças humanas que museu no Reino Unido decidiu deixar de exibir. BBC 23 set. 2020. Disponível em: https://www.bbc.com/portuguese/brasil-54259767/ Acesso em: 26 mar. 2021.

VIEIRA, Marina Cavalcante, A Exposição Antropológica Brasileira de 1882 e a exibição de índios botocudos: performances de primeiro contato em um caso de zoológico humano brasileiro. Revista Horizonte antropológico, Porto Alegre, ano 25, n. 53, p. 317-357, jan./abr. 2019. Disponível em: https://www.scielo.br/pdf/ha/v25n53/1806-9983-ha-25-53-317.pdf/. Acesso em: 24 maio 2021.

YALE. Statement from Yale University Regarding Machu Picchu Archaeological Materials. Em 21 nov. 2010. Disponível em: http://news.yale.edu/2010/11/21/statement-yale-university-regardingmachu-picchu-archaeological-materials Acesso em: 26 abr. 2021. 